\title{
Energy Savings Across EU Domestic Building Stock by Optimizing Hydraulic Distribution in Domestic Space Heating Systems
}

\author{
Ciara Ahern \\ Technological University Dublin, ciara.ahern@tudublin.ie \\ Brian Norton \\ Technological University Dublin, brian.norton@tudublin.ie
}

Follow this and additional works at: https://arrow.tudublin.ie/engschcivart

Part of the Energy Systems Commons

\section{Recommended Citation}

Ahern, C. \& Norton, B. (2015) Energy Savings Across EU Domestic Building Stock by Optimizing Hydraulic Distribution in Domestic Space Heating Systems, Energy and Buildings vol. 91, pp.199-209. doi:10.1016/ j.enbuild.2015.01.014

This Article is brought to you for free and open access by the School of Civil and Structural Engineering at ARROW@TU Dublin. It has been accepted for inclusion in Articles by an authorized administrator of ARROW@TU Dublin. For more information, please contact arrow.admin@tudublin.ie, aisling.coyne@tudublin.ie, gerard.connolly@tudublin.ie.

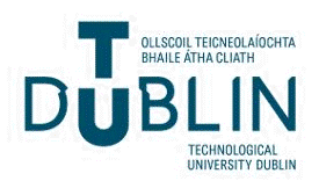




\title{
Energy savings across EU domestic building stock by optimizing hydraulic distribution in domestic space heating systems
}

\author{
s Q1 Ciara Ahern $^{\mathrm{a}, *}$, Brian Norton ${ }^{\mathrm{b}}$ \\ a Dublin Energy Lab, Department of Building Services, School of Mechanical and Design, Dublin Institute of Technology, Rm 245, Bolton St., Dublin 1, Ireland \\ ${ }^{\mathrm{b}}$ Dublin Energy Lab, Dublin Institute of Technology, Grangegorman, Dublin 7, Ireland
}

\section{A R T I C L E I N F O}

Article history:

Received 21 November 2014

Received in revised form 8 January 2015

Accepted 9 January 2015

Available online $\mathrm{xxx}$

\section{Keywords:}

Space heating efficiency

Domestic space heating

Energy conservation residential sector

\begin{abstract}
A B S T R A C T
The objective of this work is to quantify the resultant savings across the EU from the optimization of existing system components in domestic space heating distribution systems to maintain comfort levels. Heat energy savings are shown to range from $1 \%$ to $19 \%$ depending on dwelling type, age, location and initial specific heat energy consumption. Total potential savings across the sector amount 22.6 Mtoe, a reduction of $7.3 \%$; $53 \%$ of these from a reduction in pumping power required by heating distribution systems and $47 \%$ of these from a reduction in the heat energy consumed by heating systems. The carbon abatement potential is estimated to be 496 million tonnes of $\mathrm{CO}_{2}$ equivalent. Regulatory changes to the domestic replacement and maintenance industry are required for these low-cost, high impact and highly applicable energy saving measures to be adopted more extensively.
\end{abstract}

(C) 2015 Elsevier B.V. All rights reserved.

\section{Introduction}

Building energy consumption represented $41 \%$ (up from $37 \%$ in 1990) of total final European Union (EU) energy consumption in $2010,27 \%$ of which was consumed in residential buildings and $14 \%$ in non-residential buildings. As can be seen in Fig. 1.0.1, buildings are the second largest end-use, followed by transport, and industry. Dwellings constitute $76 \%$ of the total building floor area in the EU, 65\% of which, as shown in Fig. 1.0.2, is attributed to houses [1]. Annual unit consumption per $\mathrm{m}^{2}$ for residential buildings in European Union (EU) is around $200 \mathrm{kWh} / \mathrm{m}^{2}$ [1]. In the $27 \mathrm{EU}$ member states in 2009 (EU 27), space heating consumed $68 \%$ of energy used in the residential sector, accounting for 210 million tonnes of oil equivalent (Mtoe) or 244.23 TWh [2]

Despite the construction and occupations of new energyefficient buildings, the thermal characteristics of an existing building stock will remain dominant for a number of years simply because newer buildings are always a smaller part of the total stock. The duration of dominance of pre-existing houses depends on the rate, floor area and specification of new dwelling construction. In the United Kingdom for example it has been estimated that around $75 \%$ of dwellings that will exist in 2050 have already been constructed [3]. To achieve energy savings, energy refurbishment

\footnotetext{
* Corresponding author. Tel.: +3531402 3834 .

E-mail addresses: ciara.ahern@dit.ie, bespokeengineering@gmail.com (C. Ahern).
}

of existing houses thus needs to take place [4-6]. Energy efficiency interventions can either be 'passive', to improve the building envelope and/or 'active' to improve the building services [5,7]. The capital costs of retrofitting passive fabric improvement measures such as external insulation or replacing the active heat generation plant are unaffordable to many end-users [4,8-10]. A low initial cost is incurred upgrading particular aspects of existing active systems such as the installation of thermostatic radiator valves and/or a high efficiency heating circulation pump in the dwelling heating system.

Domestic space heating has been dominated by fossil fuels, efficiency improvement in space heating will thus reduce greenhouse gas emissions $[4,7,11-13]$. Heating system efficiency depends upon the thermal performance of the building envelope, occupancy [14] and climate, as well as the performance the system's component parts [15-20]. Whilst, in most heating systems well-functioning energy efficient components are installed these components may not be (i) optimally adjusted to the particular variations in energy load encountered and (ii) set-up to optimally communicate effectively with one another $[9,15,18,20-22]$. Seemingly innocuous inaccurate settings of individual components can lead to significant over-consumption of energy [9,20]. Energy savings can thus be realised through communication that provides optimal cooperation between existing boilers, pumps, controllers and thermostats in a typical domestic space heating system such as that shown in Fig. 1.0.3.

The objective of this work is to quantify the resultant savings across the EU from the low-cost optimization of existing system 


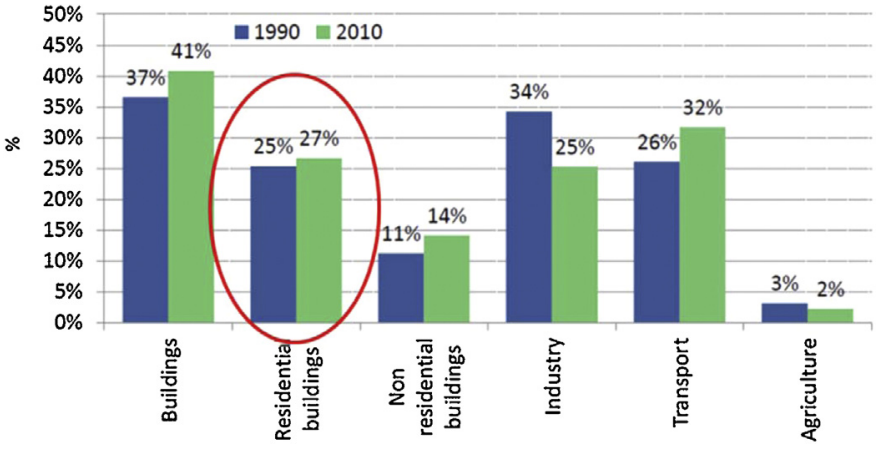

Fig. 1. Share of buildings in final energy consumption in the EU [2].

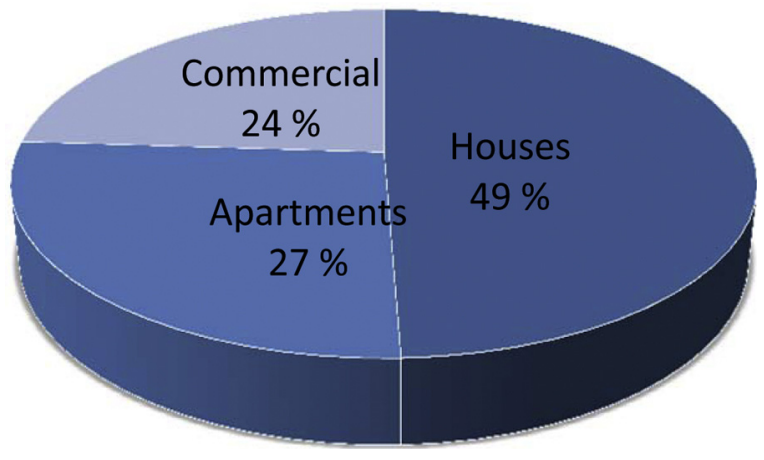

Fig. 2. Distribution of building floor area in the EU [2].

components in domestic space heating distribution systems to maintain comfort levels.

\subsection{Typical European residential space heating systems}

The majority of heating systems combust a fossil fuel to generate heat and use electrical energy to pump heat via a hydraulic distribution system to radiators $[15,17,23]$. Energy efficiency gains from heat distribution systems are not always optimal with even the most progressive energy standards failing to regulate to ensure the energy saving potential of the system is fulfilled $[4,6,9,12,15,24-26]$. A tendency to oversize heating plant leads up to $50 \%$ higher energy consumption, particularly at part load operation $[15,16,18,27,28]$. A study of 92 dwellings in Northern Germany between 2002 and 2005 found that, on average and as illustrated in Fig. 2.0.1, boilers were oversized to the peak heat load by a ratio of 1.8, pump design was typically 3 times bigger than was required, and radiators were also typically oversized by a ratio of 1.7 [20]. A

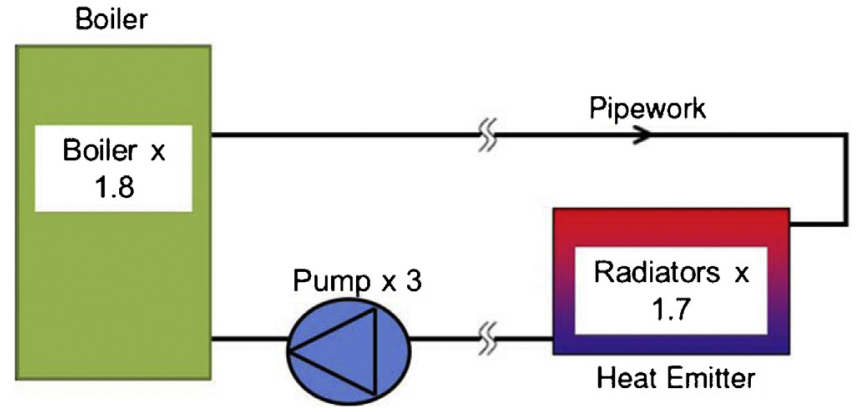

Fig. 4. Typical component oversizing [20].

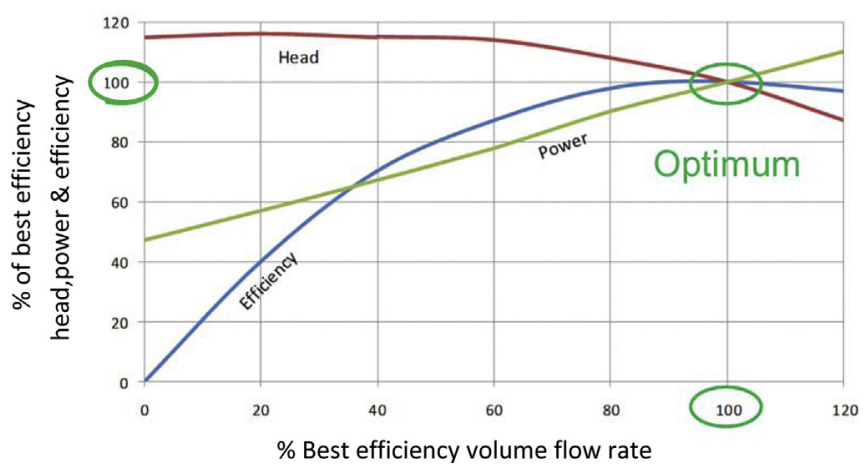

Fig. 5. Optimum operating point of a pump [31].

study of 56 dwellings in Belgium found boilers had been typically oversized by a ratio of 3 [15].

Heating circulation pumps account for 2-3\% of overall EU energy consumption in dwellings, resulting in $\mathrm{CO}_{2}$ emissions of more than 20 million tonnes in $2006[29,30]$. The efficiency of the heating circulation pump varies with its;

(i) size (flow, diameter, power)

(ii) the viscosity and temperature of fluid conveyed, and

(iii) the closeness of the pump's actual operating point to its optimal operating point.

As illustrated in Fig. 2.0.2, excessive flow rates incur unnecessary power consumption; for example doubling the flow rate results in eight times the electrical power consumption.

Hydraulic adjustment of water distribution in a pipe network is achieved by the introduction of pre-settable thermostatic radiator valves or adjustable lock shield valves as hydraulic resistors that balance flow rates. Pre-settable thermostatic radiator valves are

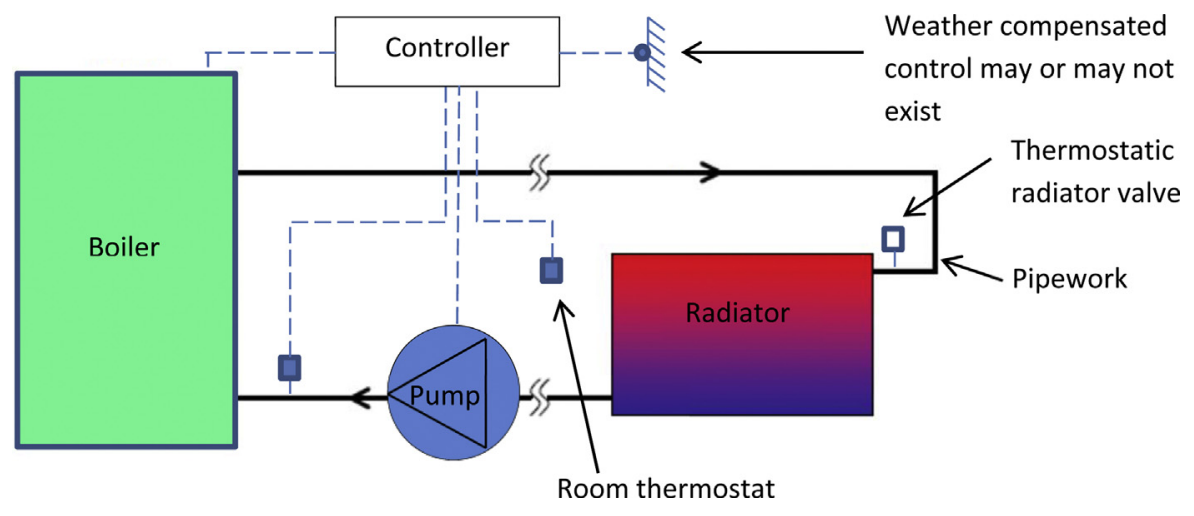

Fig. 3. Simplified typical domestic heating system. 
Table 1

Optimization interventions applied in the OPTIMUS study [40].

$\begin{array}{ll}\text { Controls } & \text { Commissioning of any pre-existing control devices for example weather compensated flow controller and adjusting heat operating times. } \\ \text { Hydraulic balancing } & \text { Hydraulic adjustment of water flow rates in the pipe network to design/optimal flow rates via pre-settable thermostatic radiator valves. } \\ \text { Pumping power } & \text { Installation of high efficiency variable speed drive pump or, at a minimum, optimising the setting of the existing fixed speed pump. } \\ & \text { Removal of bypass line and valve associated with typical fixed speed pump when high efficiency variable speed drive pump installed. } \\ \text { Insulation } & \text { Insulating the pipe network. }\end{array}$

available commercially $[32,33]$ that allow fine tuning of the heating water to optimal design flow rates.

An absence of hydraulic balancing, as shown in Fig. 2.0.3, means that;

(i) the radiator closest to the pump receives an oversupply of heating water and a greater than design heat output (red),

(ii) while radiators remote from the pump are undersupplied resulting in a lower heat output than designed (blue).

To overcome the lack of hydraulic balancing within the system either (i) the speed of the pump is increased or (ii) a larger pump can be installed, as illustrated in Fig. 2.0.4 [20,29,34,35].

The 'remedy' of oversizing of the pump is often unbeknown to the end-user who unwittingly pays the ensuing electricity costs, constituting between $5 \%$ and $10 \%$ of a typical the domestic electricity bill in 2006 [29]. The alternative remedy of increasing the speed of the pump can lead [34,36];

(i) An unacceptable noise nuisance particularly where the pump head happens to be very large.

(ii) Ineffective installed thermostatic radiator valves as their design tolerances have been exceeded.
The maximum reduction in the pump's electrical power consumption is achieved by balancing the flow rates within the distribution system via finely tuned presettable thermostatic radiator valves, as shown in Fig. 2.0.5.

Correct hydraulic balancing has been found to be present in less than $10 \%$ of heating systems with less than half of systems having pre-settable thermostatic radiator valves installed [20]. As shown in Fig. 2.0.6, a fixed speed pump used in European domestic heating systems typically has a power input in the range of 80-100 W [34]. For such systems, when the hydraulic balance is correct a $35 \mathrm{~W}$ fixed speed pump would be sufficient and either;

(i) The installation of a high efficiency variable speed drive pump or

(ii) optimizing the setting of the existing fixed speed pump curve

offers significant energy savings [34]. Athough the savings will vary from system to system, both options are viable economically under common operating conditions [37]. Energy savings in domestic heating systems of 23 TWh could be achieved across the EU by 2020 if the existing stock of fixed speed pumps were replaced with the high efficiency variable speed type circulators with an 'Ecodesign Directive' energy efficiency index in the range of $0.20-0.30[38,39]$.

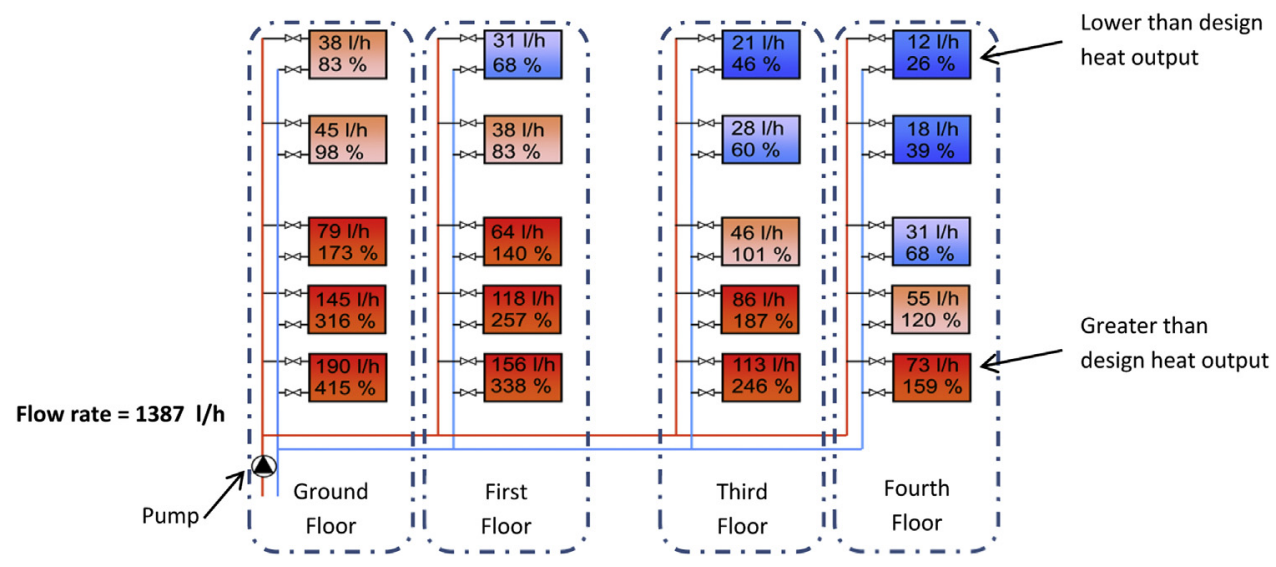

Fig. 6. Typical 'unbalanced' heating distribution system.

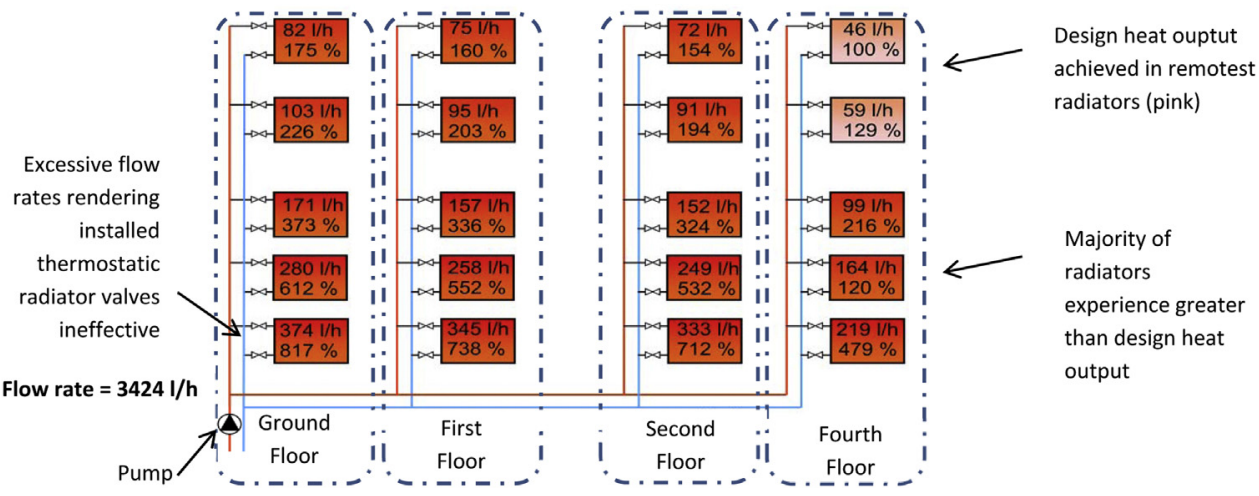

Fig. 7. Typical 'remedy’ applied to ‘unbalanced' heat distribution system. 


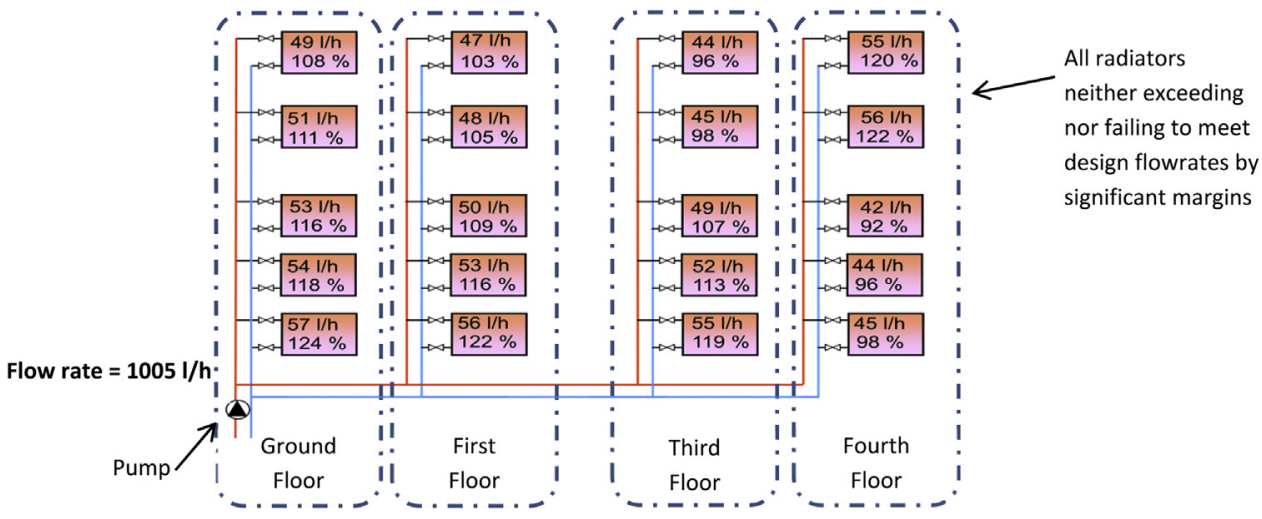

Fig. 8. Flow rates in a heating distribution system balanced by finely tuned thermostatic radiator valves.

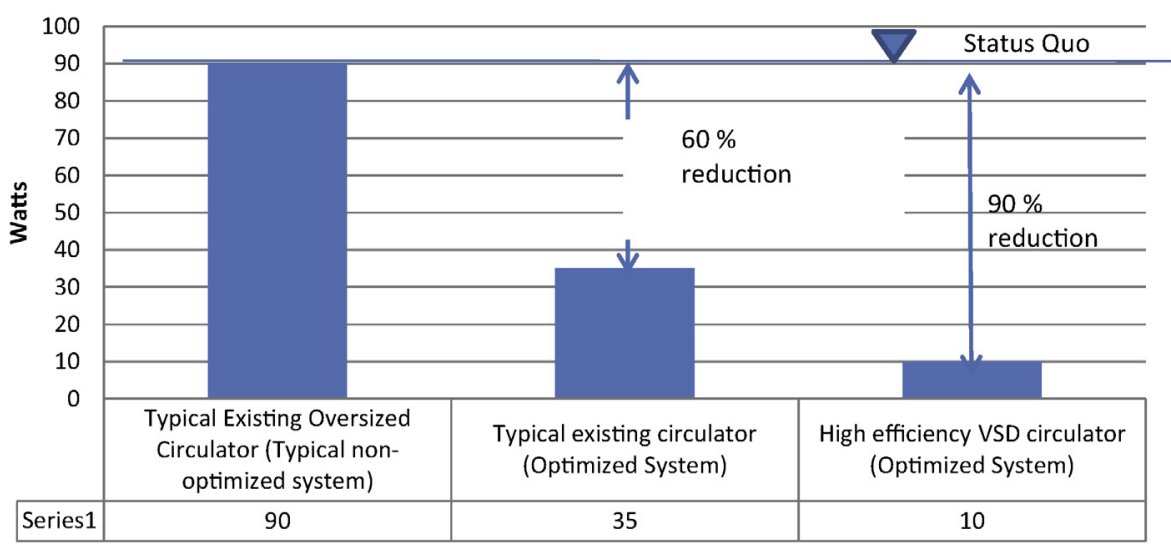

Fig. 9. Comparison of the input power of various heating pumps in different systems [34].

Under the OPTIMUS study [40], data for 75 dwellings with installed heat and electricity meters, as depicted in Fig. 2.0.7 was analysed after the 2002/2003 heating season, 19 singlefamily dwellings and 11 multi-family/apartment dwellings with relatively high heat consumption comprising were selected for some or all of the optimization interventions described in Table 2.0.1.

The heat energy consumption characteristics of 45 'nonoptimized' and 30 'optimized' systems were monitored over the $2003 / 2004$ and the 2004/2005 heating season, designated heating season $\mathrm{A}$ and $\mathrm{B}$. The benefit of heating system optimization is apparent from Fig. 2.0.8 with optimized dwellings reporting a reduced, weather adjusted energy consumption of $8 \mathrm{kWh} / \mathrm{m}^{2} / \mathrm{yr}$ between the season A and B. As shown in Fig. 2.0.8, the study notes the difference of "less than $1 \mathrm{kWh} / \mathrm{m}^{2} / \mathrm{yr}$ " in the 45 nonoptimized control buildings between seasons $\mathrm{A}$ and $\mathrm{B}$ and thus gives an adjusted reduction in energy consumption of $7 \mathrm{kWh} / \mathrm{m}^{2} / \mathrm{yr}$ through 'optimization' [19]. The adjusted Fig. of $7 \mathrm{kWh} / \mathrm{m}^{2} / \mathrm{yr}$ is used in subsequent analysis.

As shown in Fig. 2.0.9, virtually no savings were apparent through the optimization process in the oldest dwellings constructed before the installation of thermal insulation was made mandatory by building regulations in 1977 . This is evidence of heating system optimization enabling higher internal temperatures to be provided in poorly insulated dwellings [15,42]; little or no reduction in energy consumption then ensues. In some of the older dwellings surveyed, optimization measures resulted in a slight increase in heat energy consumption due to a now homogeneous heat distribution being achieved in all rooms [20,43]. Optimization interventions, therefore, at a minimum, increase comfort as more uniform heating is provided by the radiators. In newer dwellings, which have lower heat consumption due to better energetic standards, greater energy savings are realised through heating system optimization.

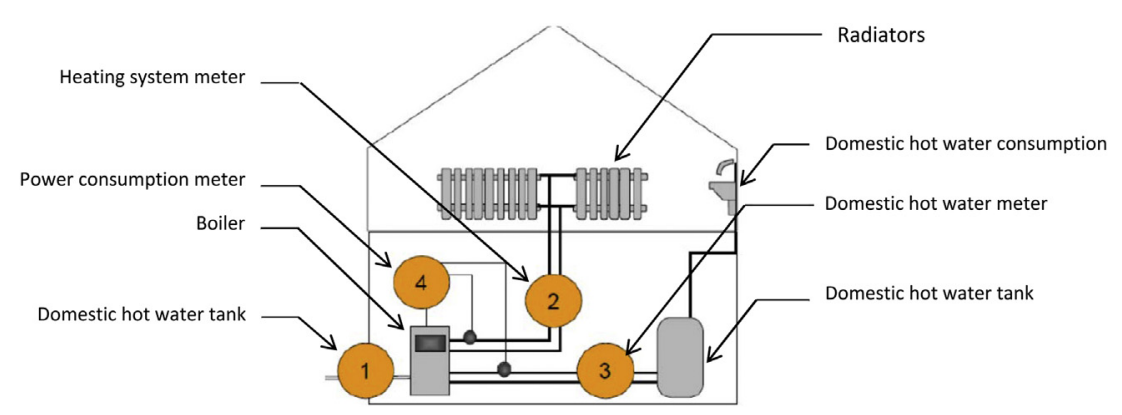

Fig. 10. Location of energy meters in relation to heating system components in the OPTIMUS study[41]. 


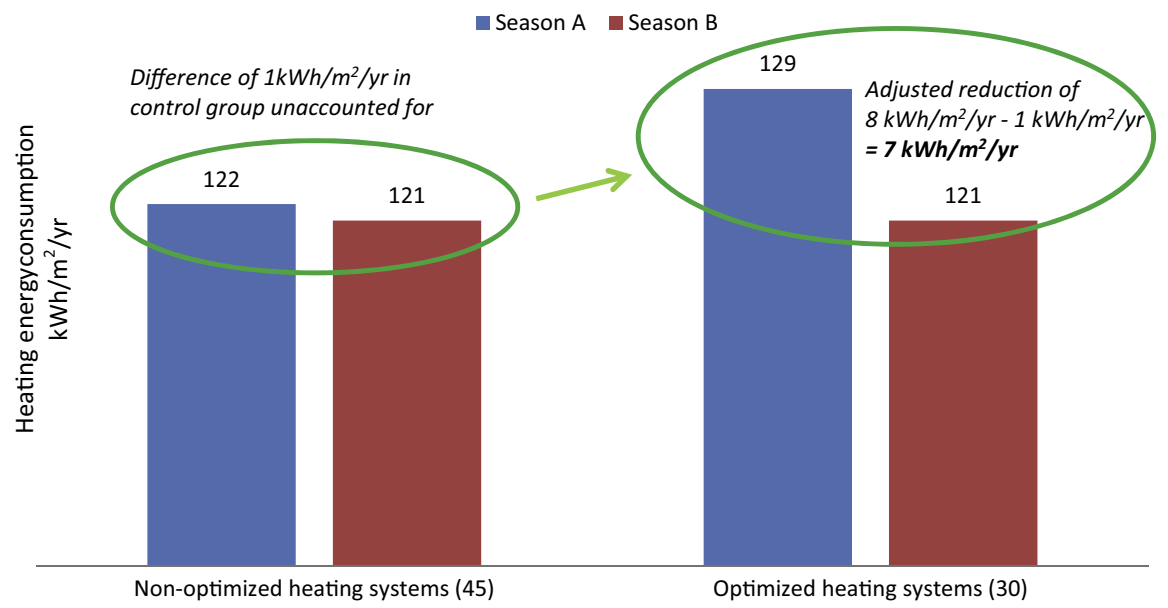

Fig. 11. Adjusted heating consumption between the optimized and non-optimized system states at system level [19].

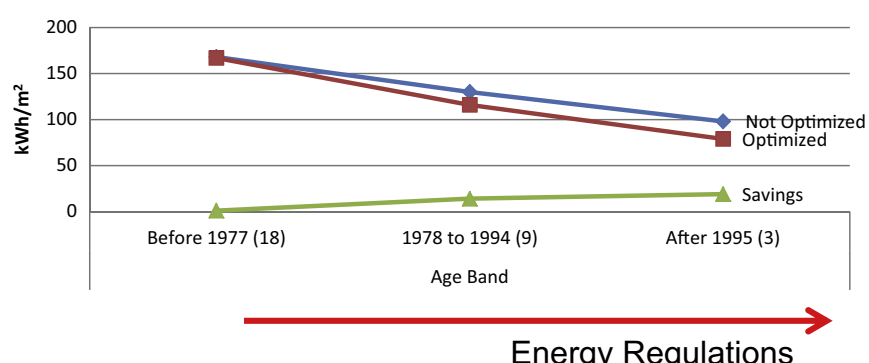

Fig. 12. Adjusted heat energy consumption pre and post optimzation by dwelling type and construction period.
The electrical energy required to pump heat to the emitters was monitored in 27 dwellings between season A and B [40]. As shown in Fig. 2.0.10, an averaged reduction of $0.38 \mathrm{kWh} / \mathrm{m}^{2} / \mathrm{yr}$ between the non-optimized and optimized system states was reported. The difference of the $0.08 \mathrm{kWh} / \mathrm{m}^{2} / \mathrm{yr}$ reported in the 38 non-optimized control dwellings between season $\mathrm{A}$ and $\mathrm{B}$ gives an adjusted reduction in energy consumption of $0.3 \mathrm{kWh} / \mathrm{m}^{2} / \mathrm{yr}$ through the optimization interventions. The adjusted figure of $0.3 \mathrm{kWh} / \mathrm{m}^{2} / \mathrm{yr}$ is used in subsequent analysis irrespective of dwelling age [19].

\subsection{Methodology}

To quantify the resultant savings across the EU from the lowcost optimization of existing system components in domestic space heating distribution systems to maintain comfort levels the potential energy savings indicated by the OPTIMUS (Wolff 2006) study were extrapolated to the full 27 states of the EU by;

(i) dwelling age

(ii) initial specific energy consumption of the dwelling $\left(\mathrm{kWh} / \mathrm{m}^{2} / \mathrm{yr}\right)$

(iii) dwelling type (single-family or multi-family), and

(iv) electrical or heat energy savings.

The methodology, summarised in Fig. 3.0.1, assumed that;

(a) the results established for a moderate climate also could be applied to warm and cold climates

(b) multiple sources of data for the housing analysis has common definitions of building type.

Base specific heat energy consumption figures $\left(\mathrm{kWh} / \mathrm{m}^{2} / \mathrm{yr}\right)$ were established under a 'business-as-usual' scenario [24] that assumes;

(i) compliance with refurbishment measures and implementation of new building codes varies between countries

(ii) refurbishment of the building stock is relatively slow and

(iii) not every refurbishment is done as it ideally should be.

The assumptions tend to conservative results. The adjusted potential heat energy savings as shown in Fig. 2.0.8 were applied to these base figures to form Table 3.0.1. In Table 3.0.1, the energy

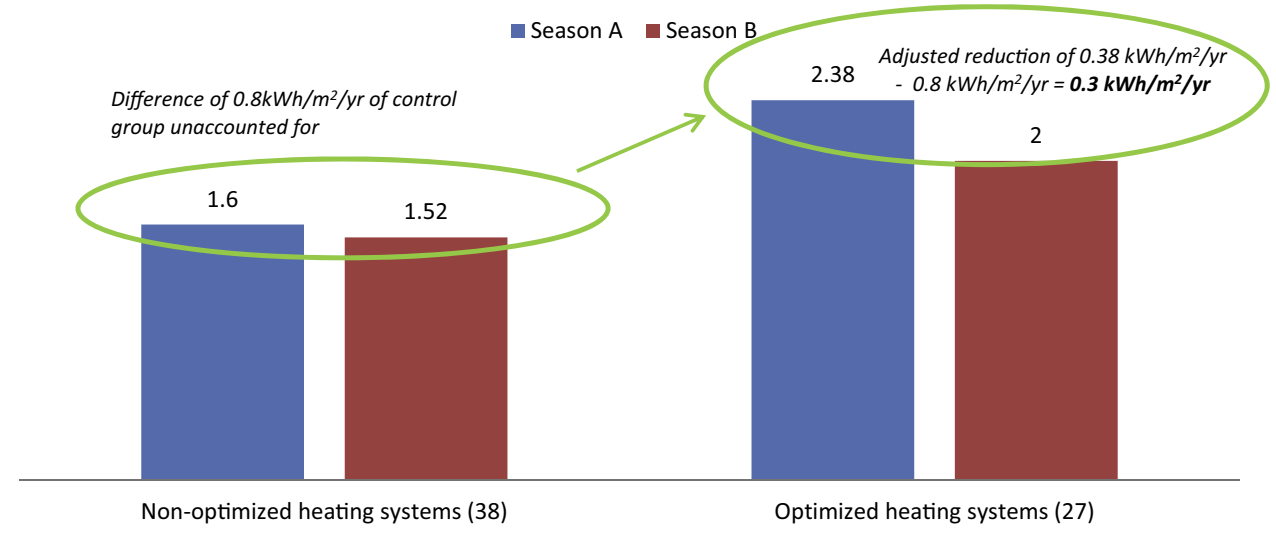

Fig. 13. Adjusted electrical consumption between the optimized and non-optimized system states [19]. 


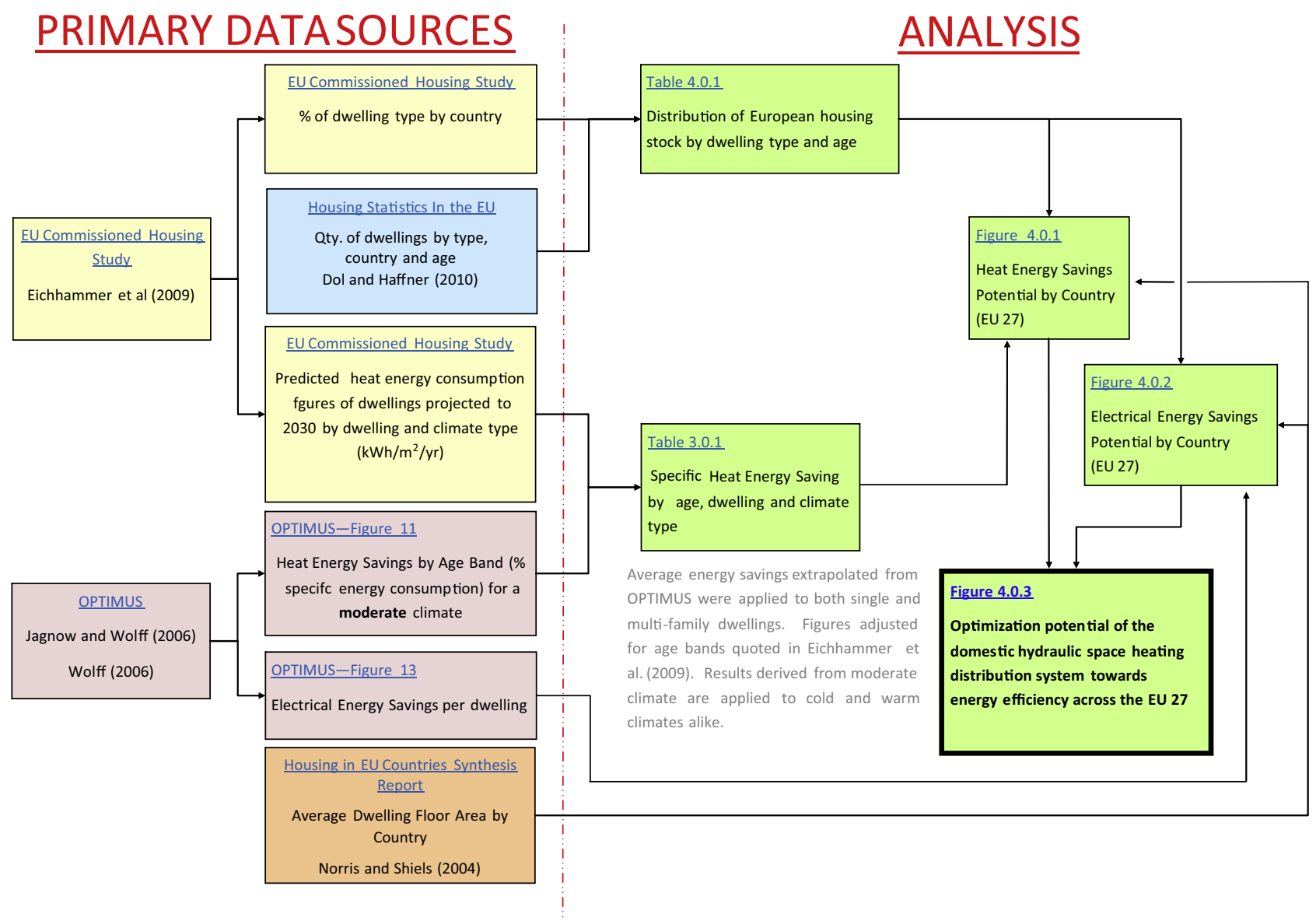

Fig. 14. Summary of primary data sources and their analysis.

savings potential of heating system optimization is shown to range from $1 \%$ to $19 \%$ depending on dwelling type, age, location and initial specific energy consumption.

Domestic heat energy consumption figures under a high-policy scenario [24] that assumes "full compliance with the respective standards" resulting in lower specific heat consumption figures than that predicted under the business-as-usual scenario. As shown in Table 3.0.2, if the adjusted potential heat energy savings shown in Fig. 2.0.9 are applied to these lower base figures, resultant savings though optimization and form a greater percentage of the whole, ranging from $1 \%$ to $30 \%$, again depending on dwelling type, age, location and initial specific energy consumption.
In order to extrapolate the potential energy savings indicated by OPTIMUS study to the full 27 states of the EU, European Dwelling stock was categorised by (i) the type of dwelling, (ii) its location and (iii) the age of dwelling. Quantity of European dwellings by dwelling type and location were established from EU housing statistics [44]. As shown in Fig. 3.0.1 and because housing statistics for some countries was not always categorised by 'dwelling type' (single-family or multi-family), data from Eichhammer et al. (2009) [24] was employed to apply typical percentage breakdowns of dwelling type by country. Subsequently, the cumulative housing data was categorised into relevant comparative age bands.

Table 2

Predicted heat energy savings by dwelling type, location and age for a 'business-as-usual' scenario.

\begin{tabular}{|c|c|c|c|c|c|c|c|}
\hline \multicolumn{8}{|c|}{ Average specific energy consumption of a single-family building $\left(\mathrm{kWh} / \mathrm{m}^{2}\right)$} \\
\hline \multirow[t]{2}{*}{ Building standard } & \multirow[t]{2}{*}{ Age band } & \multicolumn{2}{|c|}{ Cold } & \multicolumn{2}{|c|}{ Moderate } & \multicolumn{2}{|c|}{ Warm } \\
\hline & & Pre.Opt & Saving (\%) & Pre.Opt & Saving (\%) & Pre.Opt & Saving (\%) \\
\hline Old without refurbishment & Before 1977 & 197 & 1 & 269 & 0 & 272 & 0 \\
\hline Old already refurbished & Before 1977 & 158 & 1 & 225 & 0 & 212 & 0 \\
\hline Intermediate & $1978-1995$ & 165 & 8 & 219 & 6 & 188 & 7 \\
\hline New & 1995-Present & 158 & 12 & 192 & 10 & 170 & 11 \\
\hline \multicolumn{8}{|c|}{ Average specific energy consumption of a multi-family building ( $\left.\mathrm{kWh} / \mathrm{m}^{2}\right)$} \\
\hline Old without refurbishment & Before 1977 & 142 & 1 & 177 & 1 & 168 & 1 \\
\hline Old already refurbished & Before 1977 & 122 & 1 & 150 & 1 & 126 & 1 \\
\hline Intermediate & 1978-1995 & 117 & 12 & 125 & 11 & 112 & 13 \\
\hline New & 1995-Present & 113 & 17 & 118 & 16 & 102 & 19 \\
\hline
\end{tabular}

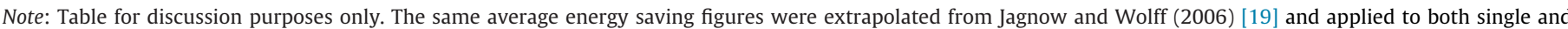

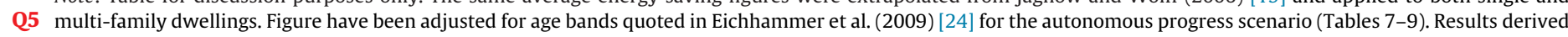
Q6 from moderate climate are applied to cold and warm climate for reference purposes only. 
Table 3

Predicted heat energy savings by dwelling type, location and age for a high policy scenario.

\begin{tabular}{|c|c|c|c|c|c|c|c|}
\hline \multicolumn{8}{|c|}{ Average specific energy consumption of a single-family building $\left(\mathrm{kWh} / \mathrm{m}^{2}\right)$} \\
\hline \multirow[t]{2}{*}{ Building Standard } & \multirow[t]{2}{*}{ Age Band } & \multicolumn{2}{|c|}{ Cold } & \multicolumn{2}{|c|}{ Moderate } & \multicolumn{2}{|c|}{ Warm } \\
\hline & & Pre.Opt & Saving (\%) & Pre.Opt & Saving (\%) & Pre.Opt & Saving (\%) \\
\hline Old without refurbishment & Before 1977 & 197 & 1 & 269 & 0 & 272 & 0 \\
\hline Old already refurbished & Before 1977 & 141 & 1 & 197 & 1 & 173 & 1 \\
\hline Intermediate & 1978-1995 & 134 & 10 & 179 & 8 & 133 & 11 \\
\hline New & 1995-Present & 122 & 16 & 137 & 14 & 107 & 18 \\
\hline \multicolumn{8}{|c|}{ Average specific energy consumption of a multi-family building ( $\left.\mathrm{kWh} / \mathrm{m}^{2}\right)$} \\
\hline Old without refurbishment & Before 1977 & 142 & 1 & 177 & 1 & 168 & 1 \\
\hline Old already refurbished & Before 1977 & 102 & 1 & 130 & 1 & 98 & 1 \\
\hline Intermediate & 1978-1995 & 93 & 15 & 86 & 16 & 75 & 19 \\
\hline New & 1995-Present & 86 & 22 & 74 & 26 & 63 & 30 \\
\hline
\end{tabular}

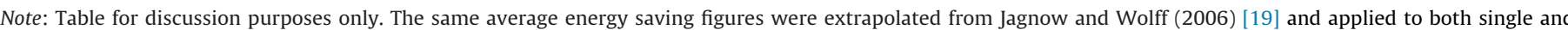

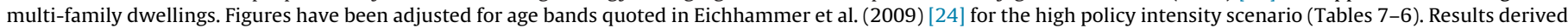
from moderate climate are applied to cold and warm climate for reference purposes only.

\subsection{Results}

The results of the housing analysis are presented in Table 4.0.1 which forms the basis of the EU housing data employed in the analysis. As illustrated in Fig. 3.0.1, average floor areas for EU dwellings were combined with

(i) EU housing data (Table 4.0.1) and savings indicated in Table 3.0.1 to calculate the potential heat energy savings by country and

(ii) the electrical savings found in Fig. 2.1.10, to calculate the potential electrical energy savings by country [45].

The heat energy saving potential resulting are presented in Figs. 4.0.1 and 4.0.2. The total heat energy savings potential of heating system optimization across the EU 27 is in the region 10.5 Mtoe or
122TWh, which amounts to circa 228 million tonnes of CO2 equivalent assuming $0.19 \mathrm{~kg}$ of $\mathrm{CO} 2$ per is produced per $\mathrm{kWh}$ of heat energy production [46]. The analysis indicates a potential to reduce the heat energy consumption of European dwellings by an average of $5 \%$, equating to an overall reduction of $3.4 \%$ across the sector. Shown in Fig. 4.0.1, are the savings by country.

The potential savings resulting from reduction in pump power required by the heat distribution system amount to $5.8 \mathrm{TWh}$, which, when a primary energy conversion factor of 2.6 is applied [47]; results in a primary energy saving of 15.08 TWh or 12.09 Mtoe. This equates to circa 268 million tonnes of $\mathrm{CO} 2$ equivalent assuming $0.19 \mathrm{~kg}$ of $\mathrm{CO} 2$ per is produced per kWh of heat energy production [46]. The resultant saving indicates a potential reduction in primary electrical energy across the sector of $3.9 \%$.

Total potential savings across the sector amount 22.6 Mtoe ( $-7.3 \%$ across the sector), $53 \%$ from savings in electrical energy and

Table 4

Distribution of European housing stock by dwelling type \& age ( $\left.{ }^{*} 1000\right)$.

\begin{tabular}{|c|c|c|c|c|c|c|c|}
\hline & & \multicolumn{6}{|c|}{ Number of dwellings (thousands) } \\
\hline & & \multicolumn{3}{|c|}{ Multi-family } & \multicolumn{3}{|c|}{ Single-family } \\
\hline & & $<1980$ & 1981-1995 & 1996-2009 & $<1980$ & 1981-1995 & 1996-2009 \\
\hline \multirow{28}{*}{ Country } & Austria & 1235 & 339 & 280 & 1162 & 319 & 263 \\
\hline & Belgium & 1133 & 297 & $\mathrm{na}^{\mathrm{a}}$ & 2861 & 752 & $\mathrm{na}^{\mathrm{a}}$ \\
\hline & Bulgaria & na $a^{a}$ & na $^{\mathrm{a}}$ & na $a^{a}$ & $\mathrm{na}^{\mathrm{a}}$ & $\mathrm{na}^{\mathrm{a}}$ & $\mathrm{na}^{\mathrm{a}}$ \\
\hline & Cyprus & 56 & 51 & 17 & 75 & 67 & 22 \\
\hline & Czech Republic & 1601 & 434 & 161 & 1190 & 322 & 120 \\
\hline & Denmark & 857 & 128 & 102 & 1256 & 188 & 150 \\
\hline & Estonia & 443 & 122 & 25 & 46 & 13 & 3 \\
\hline & Finland & 999 & 402 & 258 & 678 & 273 & 175 \\
\hline & France & 9945 & 1971 & 1726 & 12,846 & 2546 & 2229 \\
\hline & Germany & 20,776 & 4977 & 2209 & 8400 & 2012 & 893 \\
\hline & Greece & 2072 & 819 & 224 & 1563 & 618 & 169 \\
\hline & Hungary & 1254 & 384 & 126 & 1805 & 552 & 182 \\
\hline & Ireland & 62 & 30 & 38 & 708 & 342 & 440 \\
\hline & Italy & 9695 & 6579 & 4094 & 3285 & 2229 & 1387 \\
\hline & Latvia & 509 & 176 & 59 & 204 & 71 & 24 \\
\hline & Lithuania & 787 & 163 & 31 & 262 & 54 & 10 \\
\hline & Luxemburg & 60 & 5 & 3 & 106 & 9 & 5 \\
\hline & Malta & 15 & 7 & 3 & 68 & 32 & 14 \\
\hline & Netherlands & 1332 & 441 & 286 & 3265 & 1080 & 702 \\
\hline & Poland & 6026 & 2216 & 568 & 2968 & 1091 & 280 \\
\hline & Portugal & 1534 & 765 & 469 & 1534 & 765 & 469 \\
\hline & Romania & 2804 & 676 & 185 & 3568 & 861 & 236 \\
\hline & Slovakia & 651 & 217 & 33 & 625 & 209 & 32 \\
\hline & Slovenia & 300 & 79 & 28 & 288 & 76 & 27 \\
\hline & Spain & 12,081 & 3665 & 1341 & 5685 & 1725 & 631 \\
\hline & Sweden & 1981 & 299 & 181 & 1644 & 248 & 150 \\
\hline & United Kingdom & 3572 & 893 & $\mathrm{na}^{\mathrm{a}}$ & 15,228 & 3807 & $\mathrm{na}^{\mathrm{a}}$ \\
\hline & Total & 81,780 & 26,135 & 12,447 & 71,320 & 20,261 & 8613 \\
\hline
\end{tabular}

a Data not available [44]. 


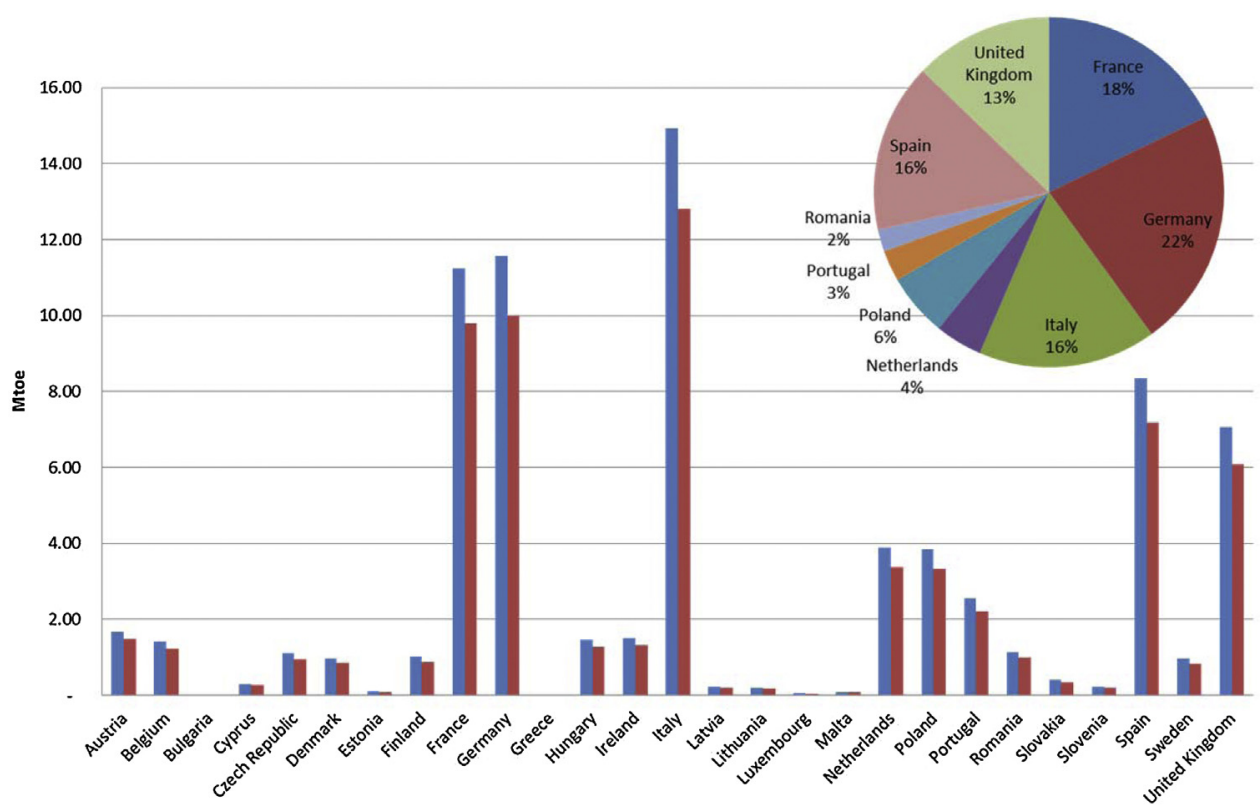

Fig. 15. Heat energy consumption of optimised vs non-optimized heating systems by country.

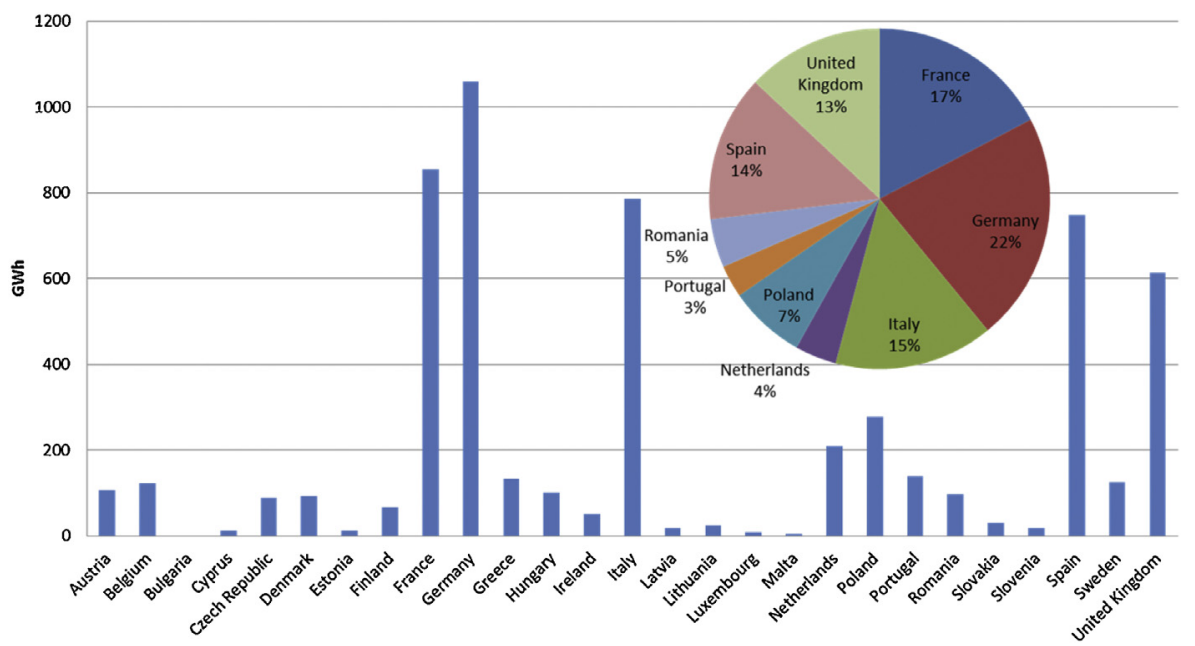

Fig. 16. Potential savings in electrical energy consumption of the optimized heating system by country (secondary energy).

$47 \%$ from heat energy consumption. The carbon abatement potential is estimated to be 496 million tonnes of $\mathrm{CO} 2$ equivalent. As shown in Fig. 4.0.3, the results are significant due to the relative energy consumption of the sector being so large (68\%). As shown in
Fig. 4.0.4, heat energy saving potential across the EU 27 is limited by the fact that $67 \%$ of the European dwelling stock was constructed prior to 1980 where no savings are apparent from the optimization process.

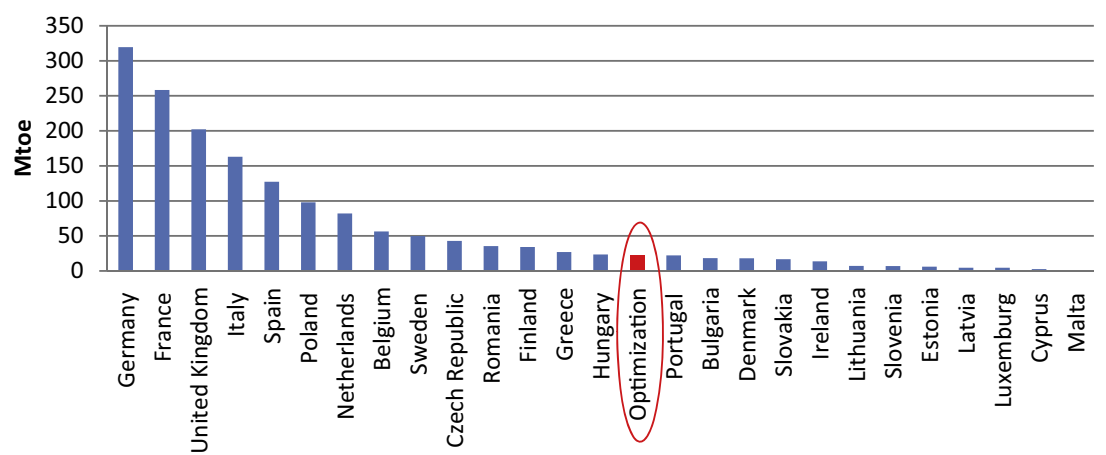

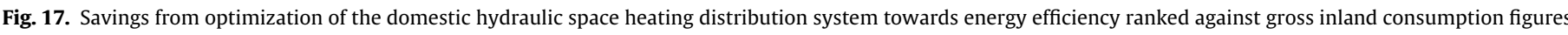
for the EU27 in 2012 [48]. 


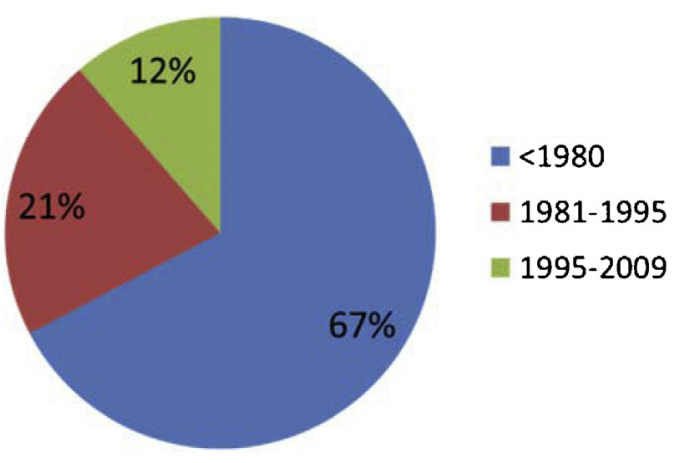

Fig. 18. Distribution of European Dwelling by Age Band [45].

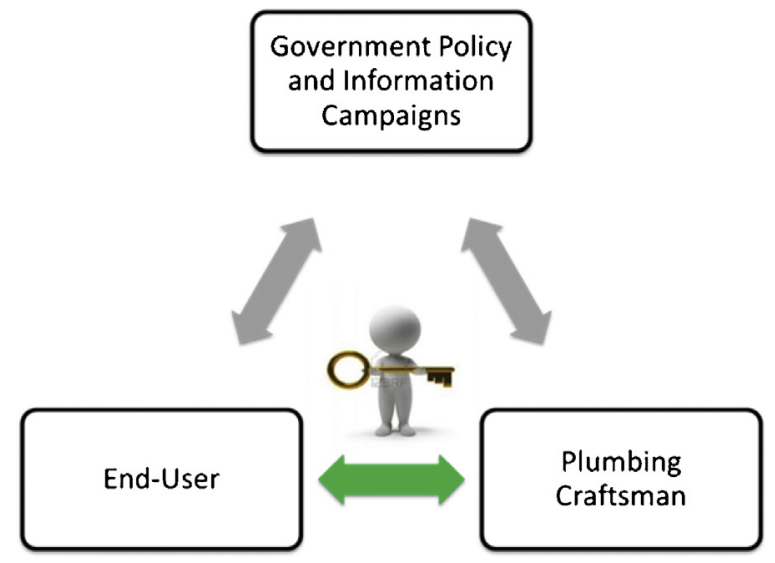

Fig. 19. Key stakeholders of the domestic plumbing and heating sector.

\subsection{Barriers to implementation}

OPTIMUS [20] reported relatively low investment costs ranging between $€ 2$ and $€ 7$ per square meter of dwelling floor area for the optimization measures applied to heating distribution systems located in Northern Germany outlaid in the years 2003 and 2004. The range in investment costs was principally dependent on whether (i) a new variable speed drive pump was installed and (ii) the number of new thermostatic radiator valves required. Average investment costs related to the heated areas for dwellings located in Northern German were reported to be $3.65 € / \mathrm{m}^{2}$ (Jagnow and Wolff 2006 [19]). This is equivalent to an average cost of $€ 438$ for a $120 \mathrm{~m}^{2}$ single family dwelling and $€ 5318$ for a $1457 \mathrm{~m}^{2}$ multifamily or apartment building. It is problematic to summarize the investment cost of optimization measures across EU countries as investment costs vary in individual countries. Even so optimization measures are low-cost, high impact and highly applicable energy saving measures; it is therefore puzzling that they are not adopted as evidenced by the low efficiencies of domestic heating systems being below expectation. To resolve this puzzle requires consideration of the market structure of the plumbing and heating sector. The key stakeholders in the sector are summarized in Fig. 5.0.1.

When building or retrofitting a house, the design and specification of the heating installation is often considered last as it does not proportionally increase the value of a property [49]. The domestic heating market is thus supply-driven, as the demand for operational energy efficiencies by the end-user is often missing $[20,30]$. As shown in Fig. 5.0.2, end-users have been found to be generally unaware of the energy saving potential of their heating system, being unconcerned about the system performance so long as it realises the desired indoor temperature [4,15,29,50,51]. Good comparative information about user settings and their effects
Respondents believe that they use most energy in the following areas

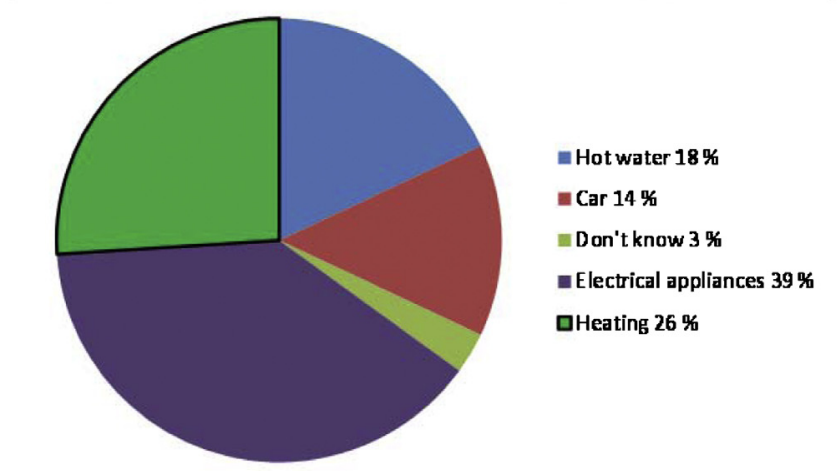

Actual consumption as a percentage

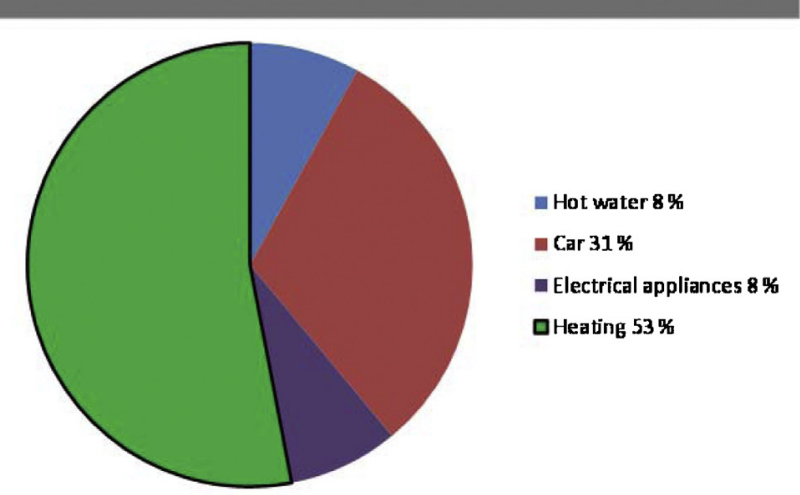

Fig. 20. End-user responses to a German domestic energy survey [52].

has not been available, for example, the majority of occupants do not know how to correctly operate installed thermostatic radiator valves $[9,10,15]$.

The determining factor in the uptake of energy efficiency upgrades in the plumbing and heating sector is the relationship between the end-user and the craftsman (or expert). Since the end-user does not have to submit the heating system to an official inspection, it is often left to the craftsman to take the initiative in promoting and adopting energy efficiency measures for the system [52]. In upgrade works the end-user needs to trust an installer's competence and the quality of the advice given [50-53]. The quality of advice can be undermined by inherent vested commercial interests in the advice provided. It is therefore important, that information campaigns ensure end-users receive the heightened expectation messages [51]. However, there is no regular European information policy for energy efficiency in residential space heating $[6,20]$. Individual installers can be trained and encouraged, supported and/or mandated to do the best possible energy efficiency upgrades of the heating systems. For instance, when carrying out repairs or modifications on a system, there could be regulations enacted to support the installer to optimize systems [20,30,54].

That EU "member states are largely underestimating the importance of energy services and the market for companies that deliver them" [12] illustrates the regulatory focus on utility and energy service companies. Very few regulatory or policy perspectives on domestic energy in the EU focus on installers as a key stakeholder in the energy services market. This is because the sector has challenging characteristics that render interventions difficult, for example in Ireland the typical plumbing craftsman in the residential market works alone or with one other and, not being a member of a national body, does not engage with any formal continuous professional development [55]. Design innovation and the 
337 complexity of the heating systems is increasing, there is therefore a requirement for continual professional development to enable the plumbing craftsman to have (i) a system level approach and (ii) a high level of responsibility for the overall efficiency of the system $[20,25,52,56,57]$. Pedagogic approaches need to be in place to produce apprentices that have good technical and communication skills to allow them to function effectively in the workplace $[56,58,59]$.

\subsection{Conclusions}

Optimization of existing space heating hydraulic distribution systems has the potential to contribute a saving of 22.6 Mtoe $(-7.3 \%$ across the sector) with an associated carbon abatement potential estimated at 496 Million Tonnes of $\mathrm{CO}_{2}$ equivalent, critically without significant investment costs to the end-user.

Plumbing craftsmen are key facilitators in realising the energy savings potential of the residential heating and plumbing sector. Their education needs to enable them to diagnose correctly system malfunctions and promote best practice optimization measures to end-users effectively [50-53,56].

Optimization of existing space heating distribution systems is low-cost and high impact. In the EU member states need to introduce domestic policy measures to address the poor energy efficiencies of heating systems in dwellings [4]. Countries should also consider regulatory measures for heating system upgrades and replacements, subsidy schemes and audit programmes

Any cause for repair should also an opportunity for optimization and/or modernization with optimization measures should be executed before introducing any expensive technology is contemplated.

Educational provision should enable plumbing craftsmen to take responsibility and be held accountable for the design and certification of heating systems in dwellings similar to that of an engineer under statutory instruments such as 'Building Control Regulations' [60].

\section{$371 \quad$ References}

[1] B. Lapillonne, C. Sebi, K. Pollier, Energy Efficiency trends for households in the EU, in: Enerdata - An Analysis Based on the ODYSSEE Database, France. Available: file: ///C:/Users/ciara.ahern/Downloads/Enerdata_201209_Energy \%20Efficiency \%20Trends \%20in \%20Buildings \%20in \%20the \%20EU.pdf.), 2012 (accessed 09.13).

[2] B. Lapillonne, C. Sebi, K. Pollier, N. Mairet, Energy Efficiency Trends in Buildings in the EU - Lessons from the ODYSSEE/MURE projects, France. Available: file:////C:/Users/ciara.ahern/Downloads/Enerdata_201209_Energy \%20Efficiency \%20Trends \%20in \%20Buildings \%20in \%20the \%20EU.pdf $\rangle$, 2012. (accessed 09.13).

[3] J. Ravetz, State of the stock-What do we know about existing buildings and their future prospects? Energy Policy 36 (12) (2008) 4462-4470.

[4] J. Weiss, E. Dunkelberg. T. Vogelpohl, Improving policy instruments to better tap into homeowner refurbishment potential: lessons learned from a case study in Germany, Energy Policy 44 (0) (2012) 406-415.

[5] S. Roberts, Altering existing buildings in the UK, Energy Policy 36 (12) (2008) $4482-4486$

[6] C. Schaefer, C. Weber, H. Voss-Uhlenbrock, A. Schuler, F. Oosterhuis, E. Nieuwlaar, R. Angioletti, E. Kjellsson, S. Leth-Peterson, M. Togeby, J. Munksgaard, Effective Policy Instruments for Energy Efficiency in Residential Space Heating - An International Empirical Analysis (EPISODE), JOULE III. Available: 〈http://elib.uni-stuttgart.de/opus/volltexte/2000/726/pdf/IER_FB_71_Episode. pdf), 2000 (accessed 10.12)

[7] IEA, Energy technology perspectives: scenarios and strategies to 2050, in: IEA (Ed.), Fact Sheet - Buildings and Appliances, IEA, France, 2006, 〈http://www.iea.org/publications/freepublications/〉 (accessed Sept. 12).

[8] C. Ahern, P. Griffiths, M. O'Flaherty, State of the Irish Housing stock - Modelling the heat losses of Ireland's existing detached rural housing stock \& estimating the benefit of thermal retrofit measures on this stock, Energy Policy 55 (2013) 139-151.

[9] T. Teich, D. Szendrei, S. Franke, S. Leonhardt, M. Schrader, Improved space heating in smart residential buildings by applying dynamic hydraulic balancing, Ann. Proc. DAAM Int. 22 (1) (2011).
[10] IEA, Energy Technology Perspectives - Scenarios and Strategies to 2050 OECD/IEA, France, 2006, 〈http://www.iea.org/media/freepublications archives/ETP2006.pdf) (accessed Aug. 14).

[11] IEA, World Energy Outlook, in, Paris, France, Available: 〈http://www. worldenergyoutlook.org/media/weowebsite/2008-1994/weo2008.pdf), 2008 (accessed Sept. 12).

[12] R. de Vos, EU energy efficiency plans - efficient enough? Renew. Energy Focus 11 (1) (2010) 44-46.

[13] EU, Action Plan for Energy Efficiency: Realising the Potential, EU Commission, Brussels, 2006, 〈http://ec.europa.eu/energy/action_plan_energy_ efficiency/doc/com_2006_0545_en.pdf (accessed Aug. 2014).

[14] Y.G. Yohanis, J.D. Mondol, A. Wright, B. Norton, Real-life energy use in the UK how occupancy and dwelling characteristics affect domestic electricity use Energy Build. 40 (6) (2008) 1053-1059.

[15] L. Peeters, J. Van der Veken, H. Hens, L. Helsen, W. D'haeseleer, Control of heating systems in residential buildings: current practice, Energy Build. 40 (8) (2008) 1446-1455.

[16] CIBSE, How to design a heating system, in: CIBSE Knowledge Series, CIBSE Plymouth, UK, 2006 (ISBN-10:1-903287-79-0).

[17] Z. Liao, A.L. Dexter, The potential for energy saving in heating systems through improving boiler controls, Energy Build. 36 (3) (2004) 261-271.

[18] Z. Liao, M. Swainson, A.L. Dexter, On the control of heating systems in the UK, Build. Environ. 40 (3) (2005) 343-351.

[19] K. Jagnow, D. Wolff, OPTIMUS - Optimierung von Heizungsanlagen - 1 4 teile, Wernigerode, Germany, Available: http:/www.delta-q.de/export sites/default/de/downloads/optimus_4_teile.pdf, 2004 (accessed Apr. 2013).

[20] K.Jagnow, D. Wolff, Kurzbericht - Umweltkommunikation in der mittelständis chen wirtschaft am beispiel der optimierung von heizungssystemen durch information und qualifikation zur nachhaltigen nutzung von energieeinsparpotenzialen, OPTIMUS, Deutsche Bundesstiftung Umwelt (BDU), Germany, 2006, 〈http://www.optimus-online.de/pdf/Kurzbericht-Technik.pdf (accessed Feb. 13)

[21] Z. Liao, F. Parland, Controller efficiency improvement for commercial and industrial gas and oil fired boilers; The final report of the CRAFT project, available: http://cordis.europa.eu/project/rcn/47377_en.html, 2001.(accessed June 13).

[22] BRESCU, Heating systems and their control, BRE, UK Department of the Environment, Garston, Watford, 1996.

[23] Y.G. Yohanis, Domestic energy use and householders' energy behaviour, Energy Policy 41 (2012) 654-665.

[24] W. Eichhammer, T. Fleiter, B. Schlomann, S. Faberi, M. Fioretto, N. Piccioni, S. Lechtenbolmer, A. Schuring, G. Resch, Study on the Energy Savings Potentials in EU Member States, Candidate Countries and EEA Countries, Final Report; for the European Commission Directorate-General Energy and Transport. Available: 〈http://ec.europa.eu/energy/efficiency/studies/doc/2009_03_15_esd_efficiency potentials_final_report.pdf), 2009 (accessed Feb 2013).

[25] A. Huber, I. Mayer, V. Beillan, A. Goater, R. Trotignon, D.E. Battaglini, Refurbishing residential building: a socio-economic analysis of retrofitting projects in five European Countries. Available: http://www.fedarene.org/ documents/projects/EEW2/WSED2011/Huber.pdf, 2011 (accessed Oct 2012).

[26] V. Bürger, The assessment of the regulatory and support framework for domestic buildings in Germany from the perspective of long-term climate protection targets, Energy Policy 59 (2012) 71-81.

[27] P. Thomas, S. Moller, HVAC system size; getting it right, in: Clients Driving Innovation: Moving Ideas into Practice, Queensland University of Technology, 2006, 〈http://eprints.qut.edu.au/27251/1/27251.pdf (accessed Oct 2012).

[28] B. Crozier, in: BSRIA (Ed.), Enhancing the performance of oversized plant, BSRIA, Bracknell, UK, 2000, https://www.bsria.co.uk/download/product ?file=J5sQIeOGQ7U\%3D (accessed Sept. 13).

[29] C. Barthel, S. Thomas, Energy and Pumps - Technology Procurement for very Energy Efficient Circulation Pumps, Wuppertal Institute for Climate, Environment, Energy, 2006, 〈http://ec.europa.eu/energy/intelligent/projects/sites/ iee-projects/files/projects/documents/energy_pumps_energy_pumps_market study_en.pdf $\rangle$ (accessed Jul 2012).

[30] N. Bidstrup, M. Van Elburg, K. Lane, EU SAVE II Project, Promotion of Energy Efficiency in Circulation Pumps, especially in Domestic Heating Systems - Summary Final Report, Environmental Change Institute, Oxford University, UK, 2001, 〈http://www.eci.ox.ac.uk/research/energy/downloads/eusavepump-sumry.pdf $\rangle$ (accessed Jul. 2012)

[31] P. Waide, C. Brunner, Energy-Efficiency Policy Opportunities for Electric Motor Driven System - Working Paper, IEA, France, 2011, 〈http://www.iea.org/ publications/freepublications/publication/EE_for_ElectricSystems.pdf $\rangle$ (accessed Mar 2013)

[32] Danfoss, RA-N Radiator Valves with Integrated Presetting and Self-Sealing Tailpiece, Danfoss, 2014, http://heating.danfoss.com/PCMPDF/VDSXL202_RA_N selfseal_teamc.pdf (accessed Oct 14).

[33] Oventrop, TRV 'Series AV6 With Adjust. Presetting Angle Pattern, DN 10 3/8', Oventrop, 2014, http://www.oventrop.de/Controls/ArticleControls ArticleInfoHandler.ashx?ArticleId=1183763\&Action=GeneratePDFReport (accessed Oct 14).

[34] V.J. Nipkow, Klein-Umwalzpumpen:Wirkungsgrad Verdreifacht, Swiss Federal Office of Energy SFOE, Zurich, 1994, 〈http://www.bfe.admin.ch/php modules/enet/streamfile.php?file $=000000003780$.pdf\&name $=000000193762$ ) (accessed June 13)

[35] T. Teich, D. Szendrei, M. Scharder, J. Franziska, S. Franke, Feasibility of Integrating Heating Valve Drivers with KNX-standard for Performing Dynamic Hydraulic Balance in Domestic Buildings, in: Proceedings of

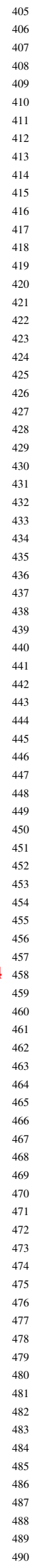


the International Conference on Electrical Power and Energy Systems, World Academy of Science, Engineering and Technology, Dubai, 2011, 〈http://waset.org/publications/8696/feasibility-of-integrating-heating-valvedrivers-with-knx-standard-for-performing-dynamic-hydraulic-balance-indomestic-buildings (accessed June 13).

[36] K. Jagnow, C. Halper, T. Tobias, Optimierung von Heizungsanlagen; Teil 3: Betrachtung der Hydraulik, in: TGA Planner - Magazine für Technische Gebäudeausrüstung (Magazine for Technical Building Equipment), SBZ Online, Germany, 2004, 〈http://www.sbz-online.de/Gentner.dll/Optimierung-vonHeizungsanlagen_MTUyMzky.PDF?UID=852AD34BFCE5132D116D37201786B 4D9F1D807821D353A9C4F) (accessed Mar. 13)

[37] H. Faulkner, Lot 11 Circulators in Buildings, Technical Study for Ecodesign Directive, Mandated by European Commission, AEA Energy \& Environment, Didcot, UK, 2008, 〈http://www.eup-network.de/fileadmin/user upload/Produktgruppen/Lots/Final_Documents/Lot11_Circulators_FinalReport. pdf) (accessed Mar 13).

[38] EU, Enterprise and Industry thematic site on EUROPA, European Union, 1995-2012, in: European Union. Available: 〈http://ec.europa.eu/enterprise/ policies/sustainable-business/ecodesign/product-groups/index_en.htm〉, 2014 (accessed Nov. 14).

[39] EU, Appendix 7, Lot 11 'Circulators in Buildings', in: Brussels. Available: 〈http://www.ebpg.bam.de/de/ebpg_medien/011_studyf_08-04_circulators_ updated.pdf), 2008 (accessed Nov 14).

[40] P. Wolff, OPTIMUS -Optimierung von Heizungsanlagen, in: Fachhochschule Braunschweig/Wolfenbuettel, Wolfenbuttel, Germany. Available: 〈http://www.hydraulischer-abgleich.de/file/optimus_4_seiten_fassung.pdf〉, 2006 (accessed Jan. 13).

[41] K. Jagnow, P. Wolff, Heizungsanlagen optimieren! - Teil 1 Uberblick. Available 〈http://www.delta-q.de/export/sites/default/de/downloads/optimus_4_teile. pdf), 2006 (accessed Mar 13).

[42] E. Dennehy, M. Howley, in: E.P.S.S. Unit (Ed.), Energy in the Residential Sector, SEAI, Dublin, Ireland, 2013, 〈http://www.seai.ie/Publications/Statistics_ Publications/Energy-in-the-Residential-Sector/Energy-in-the-ResidentialSector-2013.pdf) (accessed Jan 2014).

[43] K. Jagnow, C. Halper, T. Tobias, Optimierung von Heizungsanlagen - Teil 2: Einfluss der Anlagentechnik, in: TGA Planner - Magazine für Technische Gebäudeausrüstung (Magazine for Technical Building Equipment), SBZ Online, Germany, 2004, 〈https://www.zukunftsheizen.de/fileadmin/user_ upload/Modernisieren/Fachartikel_Optimierungskonzept.pdf) (accessed Mar 13).

[44] K. Dol, M. Haffner, Housing Statistics in the European Union 2010, OTB Research Institute for the Built Environment, Delft University of Technology, The Hague: Ministry of the Interior and Kingdom Relations, 2010, 〈https://www.bmwfw.gv.at/Wirtschaftspolitik/Wohnungspolitik/Documents/ housing_statistics_in_the_european_union_2010.pdf (accessed Oct 13).

[45] M. Norris, P. Shiels, Regular National Report on Housing Developments in European Countries Synthesis Report, Department of the Environment
(Ed.), Dublin, Ireland. Available, 〈http://www.environ.ie/en/Publications DevelopmentandHousing/Housing/FileDownLoad, 2453,en.pdf), 2004 (accessed Jul 14).

[46] RenSmart, kWh to CO2 Conversion, RenSmart, UK, 2014, /http://www. rensmart.com/Information/KWHToCO2Conversion $\rangle$ (accessed Sept. 2014).

[47] DECC, Climate Change Agreements: Interim Guidance paper GP 3.5, UK Department of energy and climate change, 2012, /https://www.gov.uk/ government/uploads/system/uploads/attachment_data/file/47819/6112-ccainterim-guidance-gp3-5.pdf (accessed Mar 2014).

[48] Eurostat, Gross inland consumption of energy, 1990-2012 (million tonnes of oil equivalent). Available: http://ec.europa.eu/eurostat/statistics-explained/ index.php/Consumption_of_energy, 2014 (accessed Nov. 14).

[49] P. Tuominen, K. Klobut, A. Tolman, A. Adjei, M. de Best-Waldhober, Energy savings potential in buildings and overcoming market barriers in member states of the European Union, Energy Build. 51 (0) (2012) 48-55.

[50] S. Emmert, M. van de Lindt, H. Luiten, BarEnergy - Barriers to changes in energy behaviour among end consumers and households - Final Report Integration of Three Emprical Studies. Available: 〈http://www.crisp-futures.eu/ download/attachments/4128781/Barenergy_FinalReport_screen.pdf?version=1 \&modificationDate=1310662311000), 2011 (accessed June 2014).

[51] K. Gram-Hanssen, F. Bartiaux, O. Michael Jensen, M. Cantaert, Do homeowners use energy labels? A comparison between Denmark and Belgium, Energy Policy 35 (5) (2007) 2879-2888.

[52] EU-OPTIMUS, EU-OPTIMUS, Saving Resources. Available: http://euoptimus.eu/, 2010 (accessed Oct 13).

[53] K. Gram-Hanssen, Residential heat comfort practices: understanding users, Build. Res. Inf. 38 (2) (2010) 175-186.

[54] Optimus, Optimus \& German Federal Environmental Foundation (Deutschen Bundesstiftung Umwelt - DBU), Germany. Available: /http://www.optimusonline.de//, 2002-2005 (accessed june 13).

[55] C. Breen, An Explorative Study into the Key Initiatives Required to Develop and Promote the Role of Competent Persons in Seai's (Sustainable Energy Authority of Ireland) Quality Assurance Framework for the Plumbing and Heating Retrofit Sector in Ireland Strategic Management, DIT, 2011 (unpublished MSc. thesis).

[56] C. Ahern, M. McGrath, EU-Optimus, A case study of a holistic systems-approach pedagogy in technology education, in: Engineering and Product Design Conference, Dublin, 2013.

[57] M. London, Redeployment and continuous learning in the $21^{\text {st }}$ Century: Hard lessons and positive examples from the downsizing era, Acad. Manag. Exec. 10 (4) (1996) 67-79.

[58] J.P. Williams, Design: the only methodology of technology? J. Technol. Educ. 11 (2) (2000).

[59] P. Sageev, C.J. Romanowski, A message from recent engineering graduates in the workplace: results of a survey on technical communication skills, J. Eng. Educ. 90 (4) (2001) 685-693.

[60] Dept_of_Environment, Building Control (Amendment) Regulations, Statutory instrument of Irish Government, Dublin, Ireland, 2014. 